\title{
TREATMENT OF MSW IN A BIOCELLREACTOR
}

\author{
Dan Waldemarson \\ Norra Asbo Renhållnings $A B$, Sweden
}

\section{ABSTRACT}

At Hyllstofta waste treatment plant municipal solid waste (MSW), pre-treated biodegradable industrial and sludge are treated in biocellreactor (BCR).

\section{METHOD}

A $6000 \mathrm{~m}^{2}$ big area was built with a bottom layer of a $1 \mathrm{~m}$ thick layer of clay with a permeability $<10^{-10}$. The clay is cowered $1 \mathrm{~m}$ sieved course till. In the top of the till layer there are 4 drainpipes I course gravel. The top surface is built with slope against the drainpipes.

MSW and biodegradable industrial waste are crushed and mixed together with biodegradable sludge. The mix is placed in $70 \mathrm{~m}$ long, $10 \mathrm{~m}$ broad and $8 \mathrm{~m}$ high piles. 10 piles were placed beside each other on the prepared area. The first pile was built up against a wall of soil on two sides. The next pile has is built next to the first one and has a soil wall only in the far short end. When the pile is about $6 \mathrm{~m}$ high we start to build pile number two and a gas drainpipe is dug about $1 \mathrm{~m}$ into the waste (Figure 1 ). About $50 \mathrm{~cm}$ under the top of the pile a perforated pipe was dug for recycling of leachate. Each pile is covered with plastic foil which is covered with paper mill sludge to prevent the wind to blow away the plastic foil.

\section{Metanproduktion BCR 5 - NARAB}

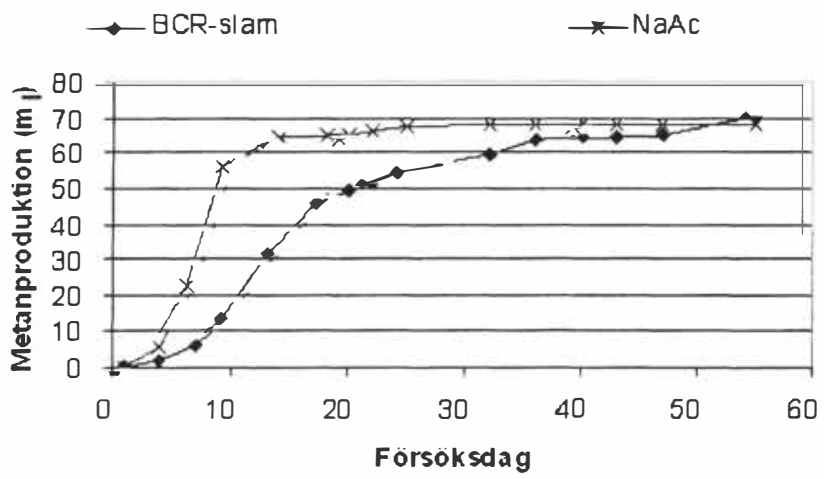

Figure 1. Activity and digestion test of the organic sludge in BCR 5. 
The leachate is collected and recycled into the cell. Gas are collected by under pressure of 0,6 bar in the cell.

\section{PURPOSE}

The purpose of the project is to digest the biodegradable part of the waste and make the MSW biologically stable with a cheap process with low investment costs.

\section{HYPOTHESIS}

After 4-5 years in the BCR all the biodegradable waste is digested and no more gas of commercial interest is possible to collect and the waste is biologically stable after 3-4 month of composting. The weight loss due to gas disposal is $25 \%-30 \%$ of the initial weight. After sieving, 30-40\% of the initial weight can be disposed as fuel, $20 \%$ can be used as soil and 10 $\%$ will be placed in the landfill. The recycled leachate should promote favourable conditions in the cell and the gas potential in the leachate is used in the cell.

\section{RESULTS}

The gas production starts within a month after the cell is sealed. The gas production varies within a great range. When building the first cells we tried different techniques. From cell 4 the techniques was established and the gas collection varies from about $40 \mathrm{~m}^{3} /$ ton to 110 $\mathrm{m}^{3} /$ ton or from $220 \mathrm{~m}^{3} /$ ton VS to $720 \mathrm{~m}^{3} /$ ton VS.

The best cell so far is number 4. This cell was sealed in the January 2002 and still produces gas. A laboratory test of the organic mater from this cell shows that there is very little gas potential left and that the waste is biologically stable (Figure 2). Cell number 5 is 5 months younger than cell 4 has produced about half as much gas and has a lot of gas potential left (Figure 3), but does not produce any gas of interest due to high oxygen content.

\section{Metanproduktion BCR 4 - NARAB}

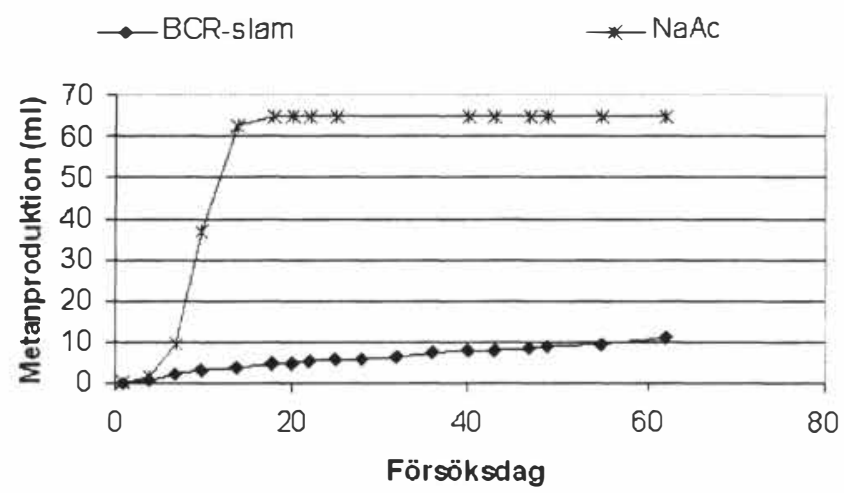

Figure 2. Activity and digestion test of the organic sludge in BCR 4. 


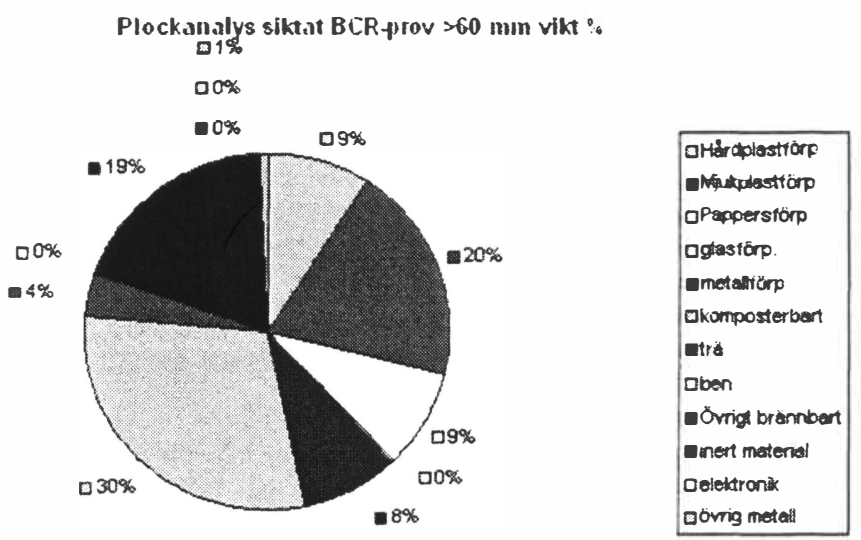

Figure 3. Hand-pick analysis of the material from BCR 1 (sample fraction $>60 \mathrm{~mm}$ ).

Cell number 1 was opened in august 2004 and 300 tons of the material was dug out. There was no problems with gas emissions or bad smell. The material was pile up and a compost process started at once. The temperature in the compost exceeded $60{ }^{\circ} \mathrm{C}$ within two days stay high for about two month. When the material was composted it was sieved first a $60 \mathrm{~mm}$ drum sieve and secondly in a $40 \mathrm{~mm}$ sieve. The three different fractions were analysed (Figure 4). The material exceeding $60 \mathrm{~mm}$ consists of $60 \%$ burnable material, $30 \%$ compost and $10 \%$ inorganic material. The fraction between $60 \mathrm{~mm}$ and $40 \mathrm{~mm}$ consists of $49 \%$ burnable, $43 \%$ compost and $8 \%$ inorganic material. The fraction smaller than $40 \mathrm{~mm}$ consists on about $75 \%$ organic material and $20 \%$ inert material and $5 \%$ of plastics. $\mathrm{Al}$ of the waste put into the cell was recycled as gas, fuel or usefull organic matter.

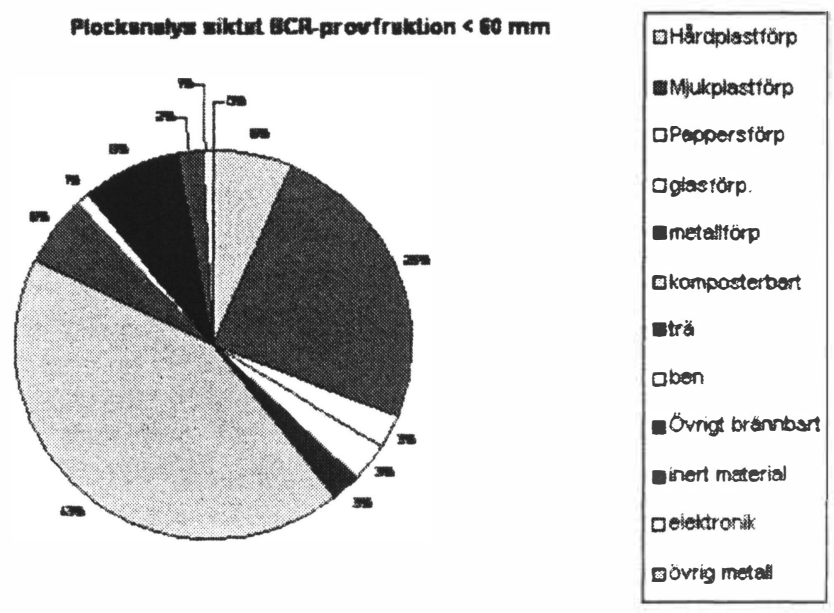

Figure 4. Hand-pick analysis of the material from BCR I (sample fraction $<60 \mathrm{~mm}$ ). 
The leachate is collected in the drainage system and recycled into the BCR. The leachate is pumped into one cell for a week and then we shift to the next cell.

The leachate composition has varied a lot from the start.

November $200123000 \mathrm{mg} / \mathrm{l}$ of $\mathrm{COD}_{\mathrm{Cr}}, 3500 \mathrm{BOD}_{7}$ and $1800 \mathrm{NH} 4-\mathrm{N}$

September $200312000 \mathrm{mg} / \mathrm{l}$ of $\mathrm{COD}_{\mathrm{Cr}_{\mathrm{r}}, 2} 100 \mathrm{BOD}_{7}$ and $1500 \mathrm{NH} 4-\mathrm{N}$

November $20032600 \mathrm{mg} / \mathrm{l}$ of $\mathrm{COD}_{\mathrm{Cr}_{r},}, 800 \mathrm{BOD}_{7}$

Maj $2005 \quad 7000 \mathrm{mg} / \mathrm{l}$ of $\mathrm{COD}_{\mathrm{Cr}}, 2600 \mathrm{BOD}_{7}$ and $2600 \mathrm{NH} 4-\mathrm{H}$

The temperature in the cells varies between $30^{\circ} \mathrm{C}$ and $50^{\circ} \mathrm{C}$ with a higher temperature in the upper parts of the cell. This could be due to leakage of air into the cell due to the lower pressure in the cell which promote composting of organic matter.

\section{DISCUSSION}

It is obvious that it is possible to reach a complete digestion of the MSW in less than 4 years if the conditions in the BCR is favourable.

We have stopped sucking gas out of some cells due to high amount of oxygen in the gas and in some cells the gas flow has disappeared. We believe that these problems are due to settling of the waste. The settling of the waste might course breakage of the gas pipe or breakage of the plastic foil covering the cell letting the air into the cell. We think that these problems are possible to overcome by some more testing. Unfortunately the environmental authorities in Sweden have band this method so Nårab can not go on developing the BCR technique. 